\title{
Integrating Attitudes to Sharia Banks in a Customer Loyalty Model of Sharia Banks: An Evidence from Indonesia
}

\author{
Mohamad Najmudin* \\ Ph.D. in Economics, Faculty of Business and Economics, Universitas Islam Indonesia \\ Condongcastur, Sleman, Yogyakarta 55281, Indonesia \\ Tulus Haryono \\ Sebelas Maret University, Jl. Ir. Sutami 36, Kentingan, Surakarta, Indonesia \\ Asmai Ishak \\ Ph.D. in Economics, Faculty of Business and Economics, Universitas Islam Indonesia \\ Condongcastur, Sleman, Yogyakarta 55281, Indonesia \\ Anas Hidayat \\ Ph.D. in Economics, Faculty of Business and Economics, Universitas Islam Indonesia \\ Condongcastur, Sleman, Yogyakarta 55281, Indonesia \\ Siswoyo Haryono \\ Ph.D. in Management, Postgraduate Studies, Universits Muhammadiyah Yogyakarta, \\ Jl. Brawijaya, Tamantirto, bantul 55183, Indonesia.
}

\begin{abstract}
The main objective of this study aimed to evaluate the role of customer attitudes towards Islamic banks and corporate image on customer loyalty through mediating customer satisfaction, trust, and switching costs. Data analysis used 283 respondents as a sample using a purposive sampling method. The research used Structural Equation Modeling (SEM) with LISREL 8.0. The findings show that of the ten hypotheses, eight hypotheses proved significant, and two hypotheses were insignificant. The results showed that attitudes towards Islamic banks affect the perception of service quality but do not affect customer satisfaction. Corporate image influences satisfaction but does not affect customer trust. Customer satisfaction affects customer loyalty, both directly and indirectly, through mediating customer trust and switching costs. The most significant total effect of attitude on Islamic banking towards loyalty has a coefficient value of 0.15 . The coefficient is the path of attitude, service quality, customer satisfaction, and customer loyalty. The pathway shows that attitudes towards sharia banking affect customer loyalty through the mediating role of service quality and satisfaction. While the most significant total effect of the corporate image through customer satisfaction, customer loyalty with a coefficient value of 0.15 . The pathway shows that corporate image influences customer loyalty through the mediation of customer satisfaction and trust.
\end{abstract}

Keywords: attitudes towards Islamic banks, customer satisfaction, service quality, switching costs, trust, customer loyalty

DOI: $10.7176 / \mathrm{JESD} / 11-10-09$

Publication date:May $31^{\text {st }} 2020$

\section{INTRODUCTION}

This research about the Islamic banking industry in Indonesia, which for the last three decades, has become one of the banking industries with rapid growth. The sharia banking business is not only conducted by purely shariabased banks, but almost all conventional banks are also Sharia banking businesses. Competition in the Islamic banking business is drastically increasing. According to Chadha and Kapoor (2009), the emergence of various forms of new technology and high customer expectations creates very competitive market conditions. A person who has a positive attitude will encourage behavior despite pressure from social norms. Three-Component Model and Attitude-behavior Consistency Theory (ABC Theory) to develop a loyalty model that explains the relationship of attitudes and the consequences of social relations that can affect loyalty.

Research Rizwan et al. (2014) sought to combine attitudes towards Islamic banks in a model of service quality, satisfaction, trust, and customer loyalty. Rizwan's research results show that customer attitudes towards Islamic banks affect customer loyalty mediated by service quality, customer satisfaction, and trust.

Research by Gures, Seda, and Sevil (2014) shows that customer satisfaction is a determining factor for high customer loyalty. Efforts in attracting new customers are much more expensive than retaining customers; customer satisfaction comes first. The correlation between customer loyalty and customer satisfaction is robust for customer segments that have high switching costs (Kotler, 2000). Customer trust reduces uncertainty when customers feel 
uncomfortable. Corporate image is intangible assets or goodwill. Companies that have the right image can generate trust, confidence, and support compared to companies that have a terrible image. An excellent corporate image will encourage customer loyalty.

Antecedents of loyalty are still partial, resulting in the absence of a research model that can predict loyalty comprehensively. As stated by Rizwan et al. (2014) by adding the variable corporate image and switching costs, and can affect customer loyalty of Islamic banks. Islamic bank services should focus on providing services that are following Islamic law because attitudes towards Islamic banks have a substantial impact on customer satisfaction. The emergence of additional costs when switching to another product will keep customers loyal. To switch to another product, the customer needs additional time to learn. This study examines the influence of customer loyalty antecedents, namely attitudes towards Islamic banks, corporate image, perceived service quality, satisfaction, trust, and switching costs to customer loyalty in Islamic banks.

\section{LITERATURE REVIEW AND HYPOTHESIS}

Effect of Attitude on Service Quality Perception and Customer Satisfaction

Attitude is the disposition to respond favorably or unfavorably to a product, person, institution, or event (Ajzen, 2005). Attitude is an internal condition of an individual that influences an individual's choice to display behavior toward an object, person, or event. Abou-Youssef et al. (2015) show that religiosity affects attitudes towards Islamic banks. More and more consumers are positively complying with Sharia law; the more significant this affects attitudes towards Islamic banks, which in turn affects consumers' perceptions of service quality. As positive as consumer attitudes are towards Islamic banks, perceptions of service quality are increasing. The provision of products offered by conventional banks but following Islamic principles can increase Muslim customer satisfaction. Rizwan et al. (2014) found attitudes towards Islamic banks affecting consumers towards customer satisfaction of Islamic banks.

$\mathrm{H}_{1}$ : Attitudes towards Islamic Banks have a positive effect on Perceptions of Service Quality

$\mathrm{H}_{2}$ : Attitudes towards Islamic Banks have a positive effect on Customer Satisfaction

\section{Effect of Service Quality Perception on Customer Satisfaction}

Service quality is a concept that accurately represents the core of a service's performance, a comparison of reliability in service encounters conducted by consumers. Parasuraman et al. (1988) proposed five dimensions of service quality: (1) Tangibles relate to physical facilities, devices, personal appearance, decoration, and communication materials. (2) Reliability is the ability to perform services accurately and reliably as promised. (3) Responsiveness is a willingness to help customers and provide services on demand quickly. (4) Assurance is the knowledge and appreciation of the staff's ability to provide trust and confidence to customers (5) Empathy includes personal care and attention to customers. High service quality will increase customer satisfaction, which encourages customer loyalty (Santouridis and Trivellas, 2010). The findings of Hong and Goo (2004) show there is a positive relationship between service quality and customer satisfaction. Service quality is an antecedent that exerts a direct influence on satisfaction and an indirect effect on loyalty.

H3: Perception of Service Quality has a positive effect on Customer Satisfaction

\section{The Effect of Corporate Image on Customer Satisfaction and Trust}

The image is an award obtained by the company because of the advantages that exist in the company. The corporate image can influence customer perception of product offerings. A positive and good corporate image can increase satisfaction and loyalty. The study by Jani and Han (2014) found the fact that hotel images have a significant impression on visitor satisfaction and loyalty. Companies that can build an image of their company will encourage customers to be satisfied, and customer satisfaction will increase trust, which will create customer loyalty (Haq et al., 2010).

$\mathrm{H}_{4}$ : Corporate Image significantly affects Customer Satisfaction

$\mathrm{H}_{5}$ : Corporate Image has a positive effect on Customer Trust

The Influence of Customer Satisfaction on Switching Cost and Customer Trust

Kotler (2003) defines customer satisfaction as someone's likes or dislikes for a product after comparing the performance of the product with the expected. The main factor of customer satisfaction is the absence of a gap between product performance. Satisfaction and switching costs can be considered an antecedent of loyalty. Switching costs as a mediating variable between customer satisfaction - customer loyalty.

Aydin and Ozer (2006) define trust as a "psychological composition" of the intention to receive something based on expectations and expected behavior from others. Customer satisfaction has a relationship with customer trust (McDougall and Levesque, 2000). The higher the customer satisfaction with the company or product, the higher the level of trust in the company or product (Kim, 2009). Higher customer satisfaction will drive higher levels of loyalty Chadha and Kapoor (2009). 
$\mathrm{H}_{6}$ : Customer satisfaction has a positive effect on switching costs

$\mathrm{H}_{7}$ : Customer Satisfaction has a positive effect on Customer Trust

$\mathrm{H}_{8}$ : Customer Satisfaction has a positive effect on Customer Loyalty

\section{Effect of Switching Costs and Customer Trust on Customer Loyalty}

Switching costs can not only be monetary but to find out the psychological influence of customers from new companies. Jones et al. (2000) state that was switching costs as an essential factor influencing the customer's decision to remain with the service provider. High switching costs, consumers are highly dependent on the seller or brand of certain products. Satisfaction and switching costs had a positive effect on customer loyalty. Switching costs are a moderating variable for the effect of satisfaction on customer loyalty and directly influence customer loyalty. The results of Chada and Kapoor's research (2009) show that switching costs affect consumer intentions to remain with certain service providers.

Trust is a willingness to rely on partners who are trusted to make exchanges. Haq et al. (2010) show that trust directly influences customer loyalty. Kishada \& Wahab (2013) showed that among the factors tested, the only trust had a positive and significant influence on customer loyalty. Amin et al. (2013) state that the creation of trust in products will encourage the creation of customer loyalty.

$\mathrm{H}_{9}$ : Switching costs have a positive effect on customer loyalty

$\mathrm{H}_{10}$ : Customer Trust positively influences Customer Loyalty

Figure 1 shows a schematic diagram and hypothesis of a research model:

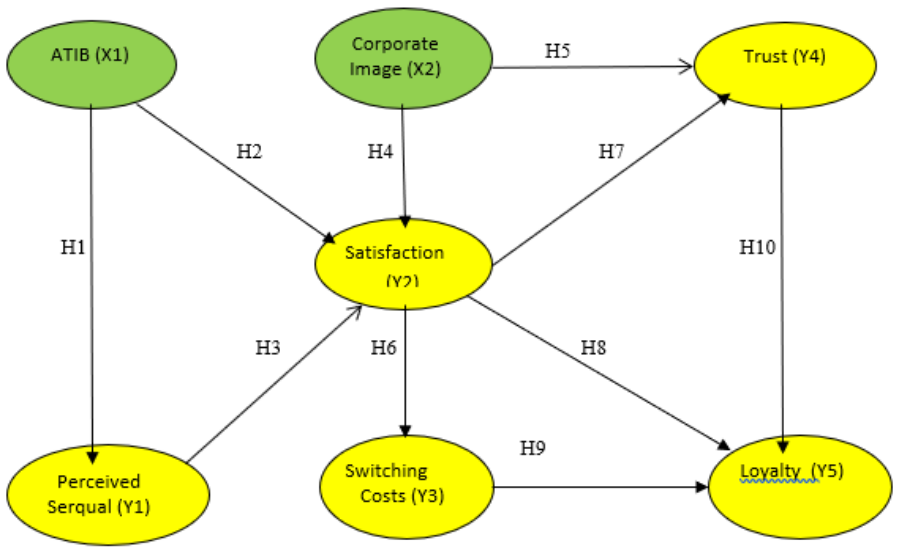

\section{METHODOLOGY RESEARCH}

The analysis of this study used Structural Equation Modeling (SEM). According to Haryono (2017), there are two stages of measurement in SEM, namely variable and structural measurements with the Confirmatory factor Analysis (CFA) method. All stages in SEM use the Goodness of Fit test. Before the inferential analysis. This method needs to test the validity and reliability of the instrument, the construct validity, and reliability.

\subsection{Population, Sample and Analysis Unit}

The population in this study is the Indonesian people who are savers at Islamic Commercial Banks.). Respondents are customers who use the services of Islamic banks for a minimum of 6 months. The researchers restricted the research area to several major cities in Java, namely the cities of Yogyakarta, Jakarta, Bandung, and Surabaya. The guidelines for the number of samples in this study are according to the SEM procedure of at least 5-10 times the number of indicators (Hair et al., 2006). This study has an indicator of 38, so the number of samples is at least $5 \times 38$ (190) to $10 \times 38$ (380). For this study, the number of samples used was 300 respondents.

\subsection{Method of collecting data}

The method of collecting data was through a survey by giving questionnaires related to the variables in this study. From 300 questionnaires, each city gets 75 questionnaires. In four major cities, customers of Sharia Commercial Banks, namely Muamalat Bank, Mandiri Syariah Bank, BRI Syariah Bank, BNI Syariah Bank, and Bukopin Syariah Bank each received 15 questionnaires.

\subsection{Variable Measurement}

The measurement scale uses a Likert Scale, which has six levels. The answer scale uses a score of 1-6 (Schiffman and Kanuk, 2010). The scales are: Strongly agree $=6$, Agree $=5$, Somewhat Agree $=4$, Somewhat disagree $=3$, 
Disagree $=2$, and Strongly Disagree $=1$. This study has seven latent constructs. Namely, attitude toward Islamic banking, service quality), customer satisfaction, trust, corporate image, switching costs, and customer loyalty.

3.4. Validity and Reliability Test of the Instrument

Test the validity of the instrument using the Pearson Correlation. All Pearson Correlation values have Sig. $<0.05$, so that all indicators are valid. While the instrument reliability test uses Cronbach Alpha $(\alpha)$. The instrument is reliable if it has Cronbach Alpha $(\alpha)>0.6$. The reliability test results show that all reliable instruments have Cronbach Alpha> 0.06 .

\section{RESULTS AND DISCUSSION}

Figure 2 shows the results of the Goodness of Fit test on the final fit model with the LISREL 8.0 application. The influence of attitudes towards Islamic banking, service quality, satisfaction, company image, trust, cost of switching to customer loyalty is fit with empirical data in the field.

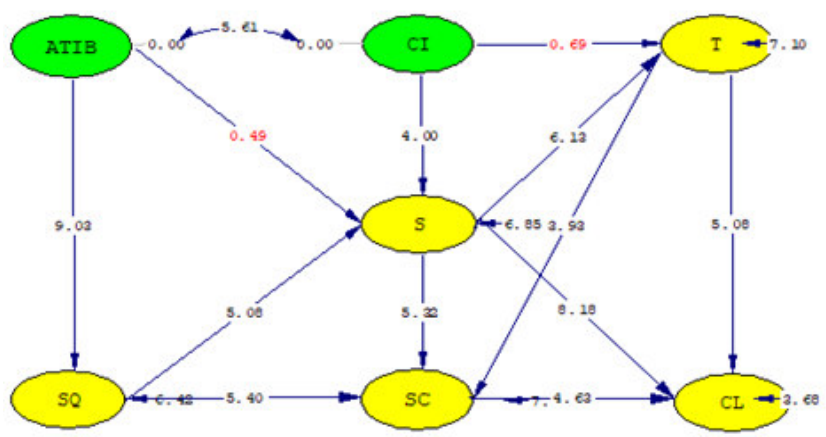

Figure 2. Structural Final Model (Model Fit) and Value of $t$

While Table 1. Is the Hypothesis Test Results

\begin{tabular}{|l|c|c|c|}
\hline \multicolumn{1}{|c|}{ Hipotesis } & Correlation & Prob. & Keterangan \\
\hline $\mathrm{H}_{1}:$ Attitude $\rightarrow$ Service Quality & + & 0.0001 & Accepted \\
\hline $\mathrm{H}_{2}:$ Attitude $\rightarrow$ Customer Satisfaction & + & 0.6248 & Rejected \\
\hline $\mathrm{H}_{3}:$ Service Quality $\rightarrow$ Customer Satisfaction & + & 0.0001 & Accepted \\
\hline $\mathrm{H}_{4}:$ Corporate Image $\rightarrow$ Customer Satisfaction & + & 0.0001 & Accepted \\
\hline $\mathrm{H}_{5}:$ Corporate Image $\rightarrow$ Customer Trust & + & 0.4912 & Rejected \\
\hline $\mathrm{H}_{6:}$ Customer Satisfaction $\rightarrow$ Switching Costs & + & 0.0001 & Accepted \\
\hline $\mathrm{H}_{7}:$ Customer Satisfaction $\rightarrow$ Customer Trust & + & 0.0001 & Accepted \\
\hline $\mathrm{H}_{8}:$ Customer Satisfaction $\rightarrow$ Customer Loyalty & + & 0.0001 & Accepted \\
\hline $\mathrm{H}_{9}:$ Switching Costs $\rightarrow$ Customer Loyalty & + & 0.0001 & Accepted \\
\hline $\mathrm{H}_{10}:$ Customer Trust $\rightarrow$ Customer Loyalty & + & 0.0001 & Accepted \\
\hline
\end{tabular}

4.1. Effect of Attitudes towards Islamic Banks towards Service Quality Perception

Table 1 shows that the attitude towards Islamic banks has a positive and significant effect on the perception of service quality $(\mathrm{SQ})(\mathrm{p}=0.0001)$. Attitude is the disposition to respond favorably or unfavorably to a product, person, institution, or event (Ajzen, 2005). Attitude is an evaluation or feeling like or dislike of an object. Attitudes towards Islamic Banks are essential in providing necessary steps to capture the attitudes of Muslim consumers towards Islamic Banks. Abou-Youssef et al. (2015) show that religiosity affects attitudes towards Islamic banks. The higher the level of one's religiosity, the more positive attitude towards Islamic banks. The results of this study are following the research of Rizwan et al. (2014), which shows that attitudes towards Islamic Banks affect consumers' perceptions of the quality of Islamic Bank services.

\subsection{Effect of Attitudes on Islamic Banks to Customer Satisfaction}

Table 1 shows that the attitude towards Islamic banks has a positive but not significant effect on customer satisfaction $(\mathrm{p}=0.6248)$. However, in the previous discussion, attitudes towards Islamic banks influenced perceived service quality, while service quality affected satisfaction. The results of this study are not in line Results of research by Rizwan et al. (2014) states that attitudes towards Islamic banks affect consumers towards customer satisfaction of Islamic banks.

4.3. Effect of Service Quality on Customer Satisfaction

Table 1 shows that the quality of service has a positive and significant effect on customer satisfaction $(\mathrm{p}=0.0001)$. 
Service quality is a measure of well-delivered services that are in line with customer expectations (Parasuraman et al., 1985). Research Donald et al. (1998) found a positive correlation between service quality and customer satisfaction. Research conducted by Parasuraman also found a positive and significant relationship between customer perceptions of service quality and their willingness to recommend companies. The results of this study supported the research by Hong \& Goo (2004), which states that service quality affects satisfaction customers.

\subsection{Effect of Corporate Image on Customer Satisfaction}

Table 1 concludes that the corporate image has a positive and significant effect on Customer Satisfaction $(p=$ 0.0001). The image has a role in marketing the organization because it has the potential to influence perception. Some customers demand higher products and services; companies need to diversify, reorganize, or because the company has a lousy event for some reason (Alma, 2000).

Research $\mathrm{Wu}$ (2014) states that corporate image acts as an essential and impressive factor in quality associations, customer evaluations, customer satisfaction, and customer loyalty.

\subsection{Effect of Corporate Image on Customer Trust}

Table 1 concludes that Corporate Image has a positive effect on Customer Trust but is not significant. $(p=0.4912)$. Haq et al. (2010) state that companies that have a good image can generate trust, confidence, and support than companies that have a bad image. Research Haq et al. (2010), which states that a company that can build an image of its company will encourage customers to be satisfied.

\subsection{Effect of Customer Satisfaction on Switch Costs}

Table 1 concludes that Customer Satisfaction has a positive and significant effect on switching costs. $(p=0.0001)$. In this study, the concept of customer satisfaction used is overall satisfaction (overall customer satisfaction). In recent decades, customer satisfaction has always been the focus of the attention of academics and marketing practitioners. This study supported the theoretical model built in this study regarding the effect of customer satisfaction on switching costs. High customer satisfaction if the perceived value exceeds customer expectations. Consumer satisfaction and trust are not only positively correlated with loyalty, but also with switching costs.

\subsection{Effect of Customer Satisfaction on Customer Trust}

Table 1 concludes that customer satisfaction has a positive and significant effect on customer trust $(\mathrm{p}=0.0001)$. Trust emerges as a conceptual variable in many studies, sometimes as an antecedent and sometimes as a consequence of other related variables. Trust leads to service quality and customer satisfaction as a consequence and follows customer loyalty as an antecedent (Ribbink et al., 2004). Trust is a fundamental component of marketing strategies in creating genuine relationships with consumers. The results of this study are in line with research by Kim (2009), which states that customer trust plays a vital role in business success. This finding supported research by McDougall and Levesque (2000, who state that customer satisfaction has a relationship with customer trust.

\subsection{Effect of Customer Satisfaction on Customer Loyalty}

Table 1 concludes that Customer Satisfaction has a positive and significant effect on Customer Loyalty $(\mathrm{p}=$ 0.0001). Customer satisfaction is the behavior, attitude, or feeling of a person towards products and services related to quality attributes that lead to overall customer satisfaction. Increasing customer satisfaction by improving the quality of service will encourage the creation of customer loyalty. This finding supported the theory built in this study regarding the effect of customer satisfaction on customer loyalty. Loyalty is a firm or deep customer commitment to products and services while ignoring other factors that cause brand switching. The results of this study prove that customer satisfaction has a strong influence on customer loyalty. Higher customer satisfaction will also encourage a higher level of loyalty (Ball et al., 2004). Customer satisfaction is directly related to customer loyalty (Kristensel et al., 2000). Almost every previous study, such Aydin and Ozer (2006), Chadha and Kapoor (2009), and Amin et al. (2013) revealed the significant influence of customer satisfaction on customer loyalty. is almost shown by every previous study, such as Aydin and Ozer (2006), Chadha and Kapoor (2009), and Amin et al. (2013).

\subsection{Cost Effect Turns On Customer Loyalty}

Table 1 concludes the Cost Switching has a positive and significant effect on Customer Loyalty $(\mathrm{p}=0.0001)$. Switching costs are all costs that must be incurred by consumers when the process of moving from certain service providers to other service providers (Burnham et al., 2003). This finding supported the theoretical model built in this study regarding the effect of switching costs on customer loyalty. Lam et al. (2004) state that switching costs have a positive and significant effect on behavioral loyalty (patronage and recommendations). Several recent findings of the direct effect of switching costs on loyalty are by Stan et al., (2013), (2014). Research Stan et al. 
(2013), the result is that switching costs positively and significantly affect customer loyalty. These findings complement the results of the study. Burnham et al. (2003) who found customer loyalty determined not only by satisfaction but also by switching costs. The significant effect of switching costs on consumer loyalty Aydin et al. (2005), Aydin and Ozer (2006), and Chada and Kapoor (2009).

\subsection{Effect of Customer Trust on Customer Loyalty}

Table 1 concludes that Customer Trust has a positive and significant effect on Customer Loyalty $(\mathrm{p}=0.0001)$. Trust is a willingness to rely on partners who are trusted to make exchanges. Cooperation relationships sare usually characterized by high trust. The results of this study supported the theoretical model built in this study regarding the effect of customer trust on customer loyalty. Trust is a crucial thing to affect commitment relationships. Specifically, trust reduces uncertainty in conditions where customers feel uncomfortable when they know they can put trust in a brand. This finding is supported by Sirdeshmukh et al. (2002) and Aydin et al., (2005), which prove the influence of consumer trust on loyalty positively and significantly.

\subsection{Total Effect Analysis}

Table 1 above shows that the most significant total effect of attitudes on Islamic banking on loyalty through Attitude path service quality, customer satisfaction, customer loyalty with a coefficient value of 0.15 . The pathway shows that the effect of attitudes towards sharia banking on customer loyalty through mediating service quality and satisfaction. While the most significant total effect of the corporate image variable through the company image path of customer satisfaction, customer loyalty with a coefficient value of 0.15 . The pathway shows that corporate image influences customer loyalty through the mediation of customer satisfaction and trust.

\section{CONCLUSIONS AND SUGGESTIONS}

From an analysis of fit structural equation models, the research findings conclude:

1. Attitudes towards Islamic Banks have a positive and significant effect on service quality.

2. Attitudes toward Islamic banks do not affect customer satisfaction.

3. Service quality significantly affects customer satisfaction.

4. The corporate image significantly affects customer satisfaction

5. The corporate image does not affect customer trust.

6. Customer satisfaction significantly affects customer trust.

7. Customer satisfaction with a coefficient value of 0.15 switching costs.

8. Customer satisfaction with a coefficient value of 0.15 impact on customer loyalty slowly.

9. The cost of switching has a positive and significant effect on customer loyalty

10. Customer trust has a positive and significant effect on customer loyalty

The most influential variable on Customer Loyalty is Customer Satisfaction with a value of 4.50, followed by Customer Trust with a value of 1.32 and a Switching Cost that has a value of 1.30. It shows that if customer satisfaction and customer trust costs move up, it will encourage the creation of customer loyalty.

From the conclusions above, the results of the research recommend to increase customer loyalty, Islamic banks should improve: positive customer attitudes toward Islamic banks, corporate image, customer satisfaction, customer trust. Moreover, the costs of switching are not burdensome.

\section{REFERENCES}

Abou-Youssef, Mariam Mourad Hussein; Kortum, Wael; Abou-Aish, Ehab; El-Bassiouny, Noha (2015), "Effects of religiosity on consumer attitudes toward Islamic banking in Egypt," The International Journal of Bank Marketing, Vol. 33 (6), pp.786-807

Amen, Muslim; Zaidi Isa; Rodrigue Fontaine (2013); "Contrasting the Drives of Customer Satisfaction on Image, Trust, and Loyalty of Muslim and Non-Muslim Customers in Malaysia," International Journal of Bank Marketing, Vol. 31, 2, pg 79-97

Andreassen, Tor Wallin dan Bodil Lindestad (1998). "Customer Loyalty \& Complex Services: the Impact of Corporate Image on Quality, Customer Satisfaction and Loyalty for Customers with Various Degrees of Service Expertise," The Intl' Journal of Service Industry Management, vol. 9, pg 7-23

Aydin, S. and Ozer, G. (2005)," National Customer SatisfactionIndices: A Implementation in the Turkish Mobile Telephone Market," Marketing Intelligence \& Planning, Vol.23, No 5

Aydin, S., and G. Ozer. 2006. How Switching Costs Affect Subscriber Loyalty in the Turkish Mobile Phone Market: An Exploratory Study. Journal of Targeting, Measurement, and Marketing Analysis. Vo.14 (2), pp. $141-155$

Ajzen, I. (2005), "Attitudes, Personality and Behavior," $2^{\text {nd }}$ Edition, New York: Open University Press McGrawHill Education

Ball, Dwayne; Pedro Simoes Coelho dan Alexandra Machas (2004), "The Role of Communication and Trust in 
Explaining Customer Loyalty," European Journal of Marketing, Vol.38,9/10, pg 1272-1293

Burnham, Thomas; Judy Frels; Vijay Mahajan (2003), "Consumer Switching Costs: A Typology, Antecedents, and Consequences," The Academy Journal of Marketing Science, Vol. 31(2)

Cardozo, Richard N. (1965), "An Experimental Study of Customer Effort, Expectation, and Satisfaction," Journal of Marketing Research, Vol.2,3, pg 244-249

Cunningham, R.M. (1956), "Brand loyalty what, where, how much?” Harvard Business

Review, Vol. 34, pp. 116-28.

Chanda S.K, Kapoor, Deepa (2009), "Effect of Switching Cost, Service Quality and Customer Satisfaction on Customer Loyalty of Cellular Service Providers in Indian Market," Journal of Marketing Management, Vol.VIII, pg 23-37

Churchill GA Jr.; C Surprenant (1982), “An investigation into the determinants of customer satisfaction, "Journal of marketing - journals.sagepub.com

Donald, D.B., Stern, G.A., Muir, D.C.G., Fowler, B.R., Miskimmin, B.M., and Bailey, R.,1998, "Chloroboranes in water, sediment, and fish from toxaphene treated and untreated lakes in western Canada." Environ. Sci. Technol. 32: 1391-1397.

Engel, J. F.; R. D. Blackwell and P W. Miniard (1995), "Consumer Behavior," Eighth Edition, Fort Worth, T.X.: Dryden $n$ Press

Erol, C. and El-Bdour, R. (1989), "Attitudes, behavior and patronage factors of bank customers towards Islamic banks," The International Journal of Bank Marketing, Vol. 7 No. 6, p. 31.

Faullant, R., Kurt Matzler dan Jhon Fuller (2008), "The Impact of Satisfaction and Image on Loyalty: The Case of Alpine Ski Resorts," Managing Service Quality, Vol.182,pg 163

Ganesan, S. (1994), "The Determinants of Long-Term Orientation in Buyer-Seller Relationships," The Journal of Marketing, 58, 1-19.

Griffin, Jill (1995), "The Customer Loyalty: How to Earn it, How to Keep It," Lexington Books; Singapore

Gronroos C. (1998), "Service quality: the six criteria of good perceived service quality," Review Bussines, Vo. 9(3), pg.10-13.

Gures, Nuriye; Arslan Seda; Tun, Sevil Yucel (2014), "The Customer Expectation, Satisfaction, and Loyalty. Relationship in Turkish Airline Industry," International Journal of Marketing Studies, Vol.6,1, pg 66-74.

Hair, Jr. Joseph F.; Rolpd E. Anderson; Ronald L. Tatham dan William C. Black (1998). "Multivariate Data Analysis (Fifth Ed.)", Upper Saddle River, New Jersey: Prentice- Hall, Inc.

Haq, Mohammad Ziaul; Sultana, Nigar; Amin, Muslim (2010), " The Effect of Trust, Customer Satisfaction and Image on Customer Loyalty In Islamic Banking Sector," South Asian Journal of Management, Vol.17.1, pg 70-93.

Hong, Sheue-Ching and Y.J. James Goo (2004), "A Causal Model of Customer Loyalty in Profesional Firm: An Empirical Study," International Journal of Management, Vol.21, pg 531-540

Jani, Dev \& Han, Heesup (2014), "Testing the Moderation Effect of Hotel Ambience on the Relationships Among Social Comparison, Affect, Satisfaction, and Behavioral Intentions," Journal of Travel \& Tourism Marketing, Volume 31 (6), pg. 731-746

Kassim, Norizan and Abdullah, Nor Asiah (2010), "The Effect of Perceived service quality dimensions on customer satisfaction, trust, and loyalty in e-commerce setting: A Cross-cultural analysis, "Asia Pacific Journal of Marketing and Logistics, Vol.22,3, pg 352-371

Kim, Dan J. (2009), "An investigation of the effect of online consumer trust on expectation, satisfaction, and postexpectation . The Information Systems and e-Business Management, Vol. 10(2), pp.219-240

Kishida, Zeyad EM, and Norailis Ab.Wahab (2013), "Factor Affecting Customer Loyalty in Islamic Banking: Evidence From Malaysian Banks," International Journal of Business and social science; Vol. 4,7 : n/a.

Kotler, Philip, 2000, Marketing Management. Edisi Millennium, Prentice Hall Intl, Inc New Jersey.

Lada, S., Tanakinjal, G.H. \& Amin, H. (2009), "Predicting the intention to choose Halal products using the TRA (The Theory of Reasoned Action)," The International Journal of Islamic and Middle Eastern Finance and Management. Vol. 2 No. 1, pp. 66-76.

Mc. Dougall, Gordon H.G.; \& Levesque, Terrence (2000), "Customer Satisfaction with Services: Putting Perceived Value into the Equation," Journal of Services Marketing, Vol.14(5), pp.392-410

Oliver, R.L. (1997), "The Satisfaction: A Behavioral Perspective on the Consumer." The McGraw-Hill Companies, Inc., New York.

Parasuraman, A.; Valerie A. Zeithaml \& Leonard L. Berry (1985), "A Conceptual Model of Service Quality and Its Implications for the Future Research," The Journal of Marketing, Vol.49, pg 41-50

Rizwan, M; Yaseen, G; Nawaz, A; Hussain, L (2014), "Incorporating Attitude towards Islamic Banking in An Integrated Service Quality, Satisfaction, Trust and Loyalty Model" Macrothink Institute, Vol 4, No. 2

Santorini, Ilias \& Panagiotis, Trivellas (2010), "Investigating the Impact of Service Quality and Consumer Satisfaction on Consumer Loyalty in Mobile Telephone in Greece," The TQM Journal, vol.22.3, pg 330-343 
Schiffman, Leon G; Kanuk, Leslie Lazar (2010), " Consumer behavior: Motivation research Marketing," Pearson Prentice Hall

Smith, Robert E and William R Swinyard (1983), “ Attitude Behavior Consistency_ The Impact of Product Trial Versus Advertising," Journal of Marketing Research, vol 20, pg 257-267

Taurus, Daniel; Rabach, Nicholas (2013), "Determinants of customer loyalty in Kenya: Does corporate image play a moderating role?", TQM Journal, Volume 25 (5)

Youssef, Abou M.M.H.; Kortam, W., Abou-Aish and El-Bassiouny, N. (2015), "Effects of religiosity on consumer attitudes toward Islamic banking in Egypt," International Journal of Bank Marketing, Vol. 33 No. 6, pp. 786807.

Zanna, Mark P. (1989). "attitude-behavior Consistency: Fulfilling the Need for Cognitive Structure," Advances in Consumer Research, Vol. 16, pg 318-320 